\title{
PEER CARING BEHAVIORS DAN DUKUNGAN SOSIAL TERHADAP PERILAKU CARING MAHASISWA SARJANA KEPERAWATAN FAKULTAS KESEHATAN DI UNIVERSITAS HARAPAN BANGSA
}

\author{
Tri Sumarni, Indri Heri Susanti, Agung Permana \\ Universitas Harapan Bangsa Jalan Raden Patah No. 100 Purwokerto Jawa Tengah \\ Email: trisumarni@uhb.ac.id
}

\begin{abstract}
ABSTRAK
Perilaku caring dipandang sebagai bagian penting dari keperawatan dan sebagai kompetensi yang diharapkan pada mahasiswa keperawatan.Kelompok teman sebaya sangat berguna dalam menyediakan lingkungan di mana mahasiswa keperawatan dapat belajar caring. Dukungan sosial juga penting untuk pengembangan profesional dan pribadi mahasiswa keperawatan.Tujuan dari penelitian ini untuk menganalisis hubungan peer caring behavior dan dukungan sosial dengan perilaku caring mahasiswa keperawatan. Penelitian ini merupakan penelitian deskriptif korelasional dengan pendekatan cross sectional. Sampel penelitian ini adalah mahasiswa program studi sarjana keperawatan sebanyak 250 mahasiswa yang terdiri dari semester 4, 6 dan 8 teknik pengambilan sampel menggunakan total sampling. Instrumen penelitian yang digunakan perilaku caring diadaptasi dari kuesioner Caring Behavior Inventory (CBI) dan kuesioner Peer Caring Behavior Scale serta Social Support Questionnaire. Hasil: Ratarata peer caring behaviors 63,1 , rata-rata dukungan sosial 16,5 , rata-rata perilaku caring 129,3 , ada hubungan peer caring behavior dengan perilaku caring $(r=0,269, p=0,015)$ dan hubungan dukungan sosial dengan perilaku caring $(r=0,215, p=0,01)$. Kesimpulan: terdapat hubungan antara peer caring behavior dan dukungan sosial dengan perilaku caring. Pendidik harus mendorong pelaksanaan perilaku caring diantara teman sebaya di kalangan mahasiswa sebagai sarana memfasilitasi hubungan mahasiswa dengan pasien dan keluarganya di masa yang akan datang. Pendidik juga mempertimbangkan peran potensial yang berkembang dari teknologi media sosial sebagai sumber dukungan sosial yang dapat diakses dan sebagai media pembelajaran dalam peningkatan perilaku caring.
\end{abstract}

Kata Kunci: peer caring behaviors; dukungan sosial; perilaku caring mahasiswa keperawatan

\section{PEER CARING BEHAVIORS AND SOCIAL SUPPORT TOWARDS CARING BEHAVIOR OF BACHELOR NURSING STUDENTS AT FACULTY OF HEALTH HARAPAN BANGSA UNIVERSITY}

\begin{abstract}
Caring behavior is seen as an important part of nursing and as an expected competency in nursing students. Peer groups are very useful in providing an environment in which nursing students can learn caring. Social support is also important for the professional and personal development of nursing students. The purpose of this study was to analyze the relationship between peer caring behavior and social support towards nursing students' caring behavior. This research was a descriptive correlational study with a cross sectional approach. The sample of this study was 250 undergraduate nursing students consisting of semesters 4, 6 and 8. The sampling technique used total sampling. The research instrument used caring behavior was adapted from the Caring Behavior Inventory (CBI) questionnaire and the Peer Caring Behavior Scale questionnaire and the Social Support Questionnaire. The average of peer caring behavior was 63.1, the average social support was 16.5, the average caring behavior was 129.3, it is stated that there is a relationship between peer caring behavior and caring behavior $(r=0.269, p=0.015)$ and the relationship between social support and caring behavior $(r=0.215, p=0.01)$. There is a relationship between peer caring behavior and social support with caring behavior. Educators must encourage the implementation of caring behavior among students as a means of facilitating student relations with patients and their families in the future. Educators also consider the developing potential role of social media technology as an accessible source of social support and as a learning medium in enhancing caring behavior.
\end{abstract}

Keywords: peer caring behavior;social support; caring behavior; nursing student's caring behaviour 


\section{LATAR BELAKANG}

Perilaku caring merupakan inti dari praktik keperawatan dan kemampuan caring merupakan komponen yang diharapkan pada mahasiswa keperawatan (Baker, 2012).Perilaku caring pada mahasiswa keperawatan sangat penting karena inilah tempat pertama bagi mahasiswa untuk mempelajari esensi profesi mereka (Begum \& Slavin, 2012). Sebagai calon perawat, mahasiswa keperawatan diharapkan memiliki perilaku caring yang tepat (Richardson, Percy, \& Hughes, 2015).

Perilaku caring tidak hanya dibentuk dari interaksi perawat dengan pasien, tetapi bisa dibentuk saat pendidikan, ada interaksi antara mahasiswa dengan lembaga pendidikan. Kebersamaan dan timbal balik antara lembaga pendidikan dengan mahasiswa dapat membantu pembentukan perilaku caring ( Sawatzky et all, 2009 dalam Sumarni, 2020). Pendidikan keperawatan menjadi tempat pembentukan perilaku caring pada mahasiswa karena disinilah terjalin keterikatan satu mahasiswa dengan mahasiswa yang lainnya, mahasiswa dengan dosen (McEnroe-Petitte DM, 2015).

Watson (2012) berpendapat bahwa caring merupakan konsep utama dalam pendidikan keperawatan. Tujuan dari kurikulum berbasis caring adalah menyediakan keseluruhan konsep tentang caring sehingga dapat menjadi dasar mahasiswa dapat berperilaku caring saat sudah menjadi perawat (Zamanzadeh, Valizadeh, Azimzadeh, Aminaie, \& Yousefzadeh, 2014). Noddings (1992) dalam Warshawski, Itzhaki, \& Barnoy(2018), menyatakan bahwa terdapat empat komponen sentral dalam mengajarkan tentang caring, yaitu dengan role model, percakapan, mempraktikkan caring dan memberikan feedback ketika muncul perilaku caring.Teman sebaya menyediakan empat elemen tersebut.

Mahasiswa menggunakan teman sebaya mereka sebagaisumber daya untuk mengembangkan nilai-nilai moral.Noddings (1992) dalam Warshawski et al., (2018) menyarankan kelompok teman sebaya sebagailingkungan alternatif bagi siswa untuk belajar merawat. Teman sebaya yang berbagi lingkungan pembelajaran dan pengalaman belajar dapat memberikan dukungan instrumental yang disesuaikan dengan kebutuhan spesifik kelompok melalui pembelajaran bersama (catatan bersama, pembelajaran strategi, dll.). Teman sebaya juga dapat membantu mengembangkan dan memperbaiki keterampilan emosional melalui hubungan interpersonal sehingga akan meningkatkan keterampilan perilaku caring mahasiswa (Richardson et al., 2015).Teman sebaya penting dalam membentuk persepsi caring mahasiswa, Noddings berpendapat bahwa kelompok teman sebaya sangat berguna dalam menyediakan lingkungan di mana mahasiswa perawat dapat belajar caring.

Dukungan sosial juga penting untuk pengembangan profesional dan pribadi mahasiswa keperawatan. Hasil penelitian sebelumnya menunjukkan dukungan sosial dari keluarga dan teman dalam bentuk penggunaan media sosial (facebook, whats app) berkorelasi positif dengan persepsi mahasiswa tentang caring. Forum media sosial digunakan oleh mahasiswa untuk mendiskusikan kegiatan akademik, tetapi juga sebagai sumber daya untuk dukungan emosional misalnya mahasiswa berbagi pengalaman merekadan ketika menjalani praktik di rumah sakit, mereka akan saling memberi dukungan tentang stres yang mereka rasakan ketika praktik (Tower M, Blacklock E, Watson B, Heffernan C, 2015;Duke et al., 2017). Berdasarkan hasil penelitianTower $M$, Blacklock $E$, Watson $B$, Heffernan $C$, (2015), peningkatan penggunaan teknologi media di antara mahasiswa keperawatan bermanfaat untuk dukungan sosial.

Hasil penelitian sebelumnya menyebutkan bahwa perilaku caring mahasiswa keperawatan dalam kategori cukup (50\%) (Nursalam, Wijaya, Bakar, \& Efendi, 2015). Penelitian Sharma et al., (2016)tentang peer caring behavior menyebutkan bahwa hanya $40 \%$ responden yang sangat setuju untuk menunjukkan perhatian tentang kesehatan satu sama lain dan membantu mereka mencari bantuan medis. Hanya 29\% 
responden yang menunjukkan minat merekadalam menyelesaikan konflik antar teman sekelas, $40 \%$ responden membantu teman sekelas mereka dalam menyelesaikan masalah. 43\% responden sangat setuju untuk membimbing teman sekelas dan saling menyemangati. Warshawski et al., (2018) menyebutkan bahwa sumber dukungan sosial mahasiswa keperawatan untuk berperilaku caring lebih banyak dari dukungan keluarga dan teman (mean 3,61) dan dukungan sosial dari sosial media (mean 2,05).

Berdasarkan hasil pengamatan terhadap perilaku caring mahasiswa selama praktik di rumah sakit, mahasiswa kurang mempunyai inisiatif untuk mendekati pasien, mahasiswa juga dinilai kurang memahami teori yang dibutuhkan selama mereka praktik. Mahasiswa hanya menunggu perintah untuk melaksanakan tindakan, terlalu banyak menghabiskan waktu di ruangan dan bukan menghadapi pasien, padahal harapannya, mahasiswa memiliki semangat dalam menemui pasien serta berusaha mencari tahu bagaimana memberikan asuhan keperawatan dengan baik dan benar melalui perilaku caring kepada pasien. Tujuan penelitian ini untuk menganalisis peer caring behaviors, dukungan sosial dengan perilaku caring Mahasiswa Sarjana Keperawatan Fakultas Kesehatan di Universitas Harapan Bangsa.

\section{METODE}

Jenis penelitian ini adalah penelitian observatif yang bersifat kuantitatif dengan rancangan penelitian cross sectional, dimana pengukuran dan pengamatannya dilakukan secara simultan pada satu saat (sekaliwaktu) (Swarjana, 2014). Populasi dalam penelitian ini adalah seluruh mahasiswa Sarjana Keperawatan Fakultas Kesehatan Universitas Harapan Bangsa semester 4, 6 dan 8 yang berjumlah 250 mahasiswa. Teknik pengambilan sampel dalam penelitian ini dengan total sampling. Sampel dalam penelitian ini berjumlah 250 mahasiswa. Kuesioner menggunakan Caring Behavior Inventory (CBI) untuk mengukur perilaku caring mahasiswa keperawatan, Peer Caring Behavior Scale untuk mengukur peer caring behavior dan Social Support Questionnaire untuk mengukur dukungan sosial. Analisis data menggunakan uji statistik uji spearman.

\section{HASIL}

Tabel 1. Distribusi Frekuensi Peer Caring Behaviors, Dukungan Sosial dan Perilaku Caring di Prodi Sarjana Keperawatan Fakultas Kesehatan Universitas Harapan Bangsa Tahun 2020

\begin{tabular}{lcc}
\hline \multicolumn{1}{c}{ Variabel } & Mean+SD & Min-max \\
\hline Peer caring behaviors & $63,1 \pm 11,3$ & $28-84$ \\
Dukungan Sosial & $16,6 \pm 2,6$ & $10-20$ \\
Perilaku Caring & $129,3 \pm 14,2$ & $77-152$ \\
\hline
\end{tabular}

Berdasarkan table diatas menunjukan peer caring behaviors pada mahasiswa Sarjana Keperawatan dengan mean 63,1 dengan nilai terendah adalah 28 dan nilai tertinggi adalah 84. Distribusi dukungan social dengan mean
16,6 dan nilai terendah adalah 10 serta nilai tertinggi adalah 20. Perilaku caring pada mahasiswa ditunjukkan dengan mean 129,3, nilai terendah adalah 77 dan tertinggi adalah 152. 
Tabel 2. Hubungan Peer Caring Behaviors, Dukungan Sosial dan Perilaku CaringMahasiswa Keperawatan

\begin{tabular}{lcc}
\hline \multicolumn{1}{c}{ Variabel } & $\mathrm{R}$ & $\mathrm{p}$ value \\
\hline $\begin{array}{l}\text { Peer caring behaviors dan } \\
\text { perilaku caring }\end{array}$ & 0,269 & 0,015 \\
\hline $\begin{array}{l}\text { Dukungan social dan perilaku } \\
\text { caring }\end{array}$ & 0,215 & 0,01 \\
\hline
\end{tabular}

Tabel diatas menyatakan ada hubungan antara peer caring behaviors dengan perilaku caring yang ditunjukkan dengan nilai $p$ value 0,015 dan ada hubungan antara dukungan social dengan perilaku caring dengan $p$ value 0,01 .

\section{PEMBAHASAN}

Berdasarkan tabel 1 didapatkan bahwa mean untuk peer caring behavior yaitu 63,1, mean dukungan sosial 16,2, mean perilaku caring mahasiswa keperawatan 129,3. Berdasarkan hasil analisis kuesioner peer caring behaviors diperoleh data bahwa pada indikator dukungan (support) memperoleh nilai tertinggi (810) yaitu pada pernyataan Teman sekelas saling memberi semangat satu sama lain. Lingkungan kelas dan interaksi antar teman sekelas merupakan faktor penting dalam kehidupan sosial bagi mahasiswa keperawatan. Sering kali adanya tugas yang diberikan membuat mahasiswa harus saling bertukar pendapat. Hal ini membuat mahasiswa saling mendukung satu sama lain. Dukungan yang diberikan oleh teman sekelas sangat berarti bagi mahasiswa meski tidak dalam jumlah yang besar. Indikator membantu (doing for) memperoleh nilai terendah (620) yaitu pada pernyataan Teman sekelas saya memperhatikan apa yang saya butuhkan. Setiap mahasiswa keperawatan pada hakekatnya memiliki pendapat masingmasing serta kebutuhan yang berbeda. Namun, dalam suatu kelompok mahasiswa keperawatan sering kali terdapat perbedaan pendapat yang menyebabkan timbulnya masalah. Adanya diskusi dan saling membantu merupakan solusi untuk meminimalisir terjadinya perdebatan antara anggota kelompok.

Pendidikan keperawatan menjadi tempat pembentukan perilaku caring pada mahasiswa karena disinilah terjalin keterikatan satu mahasiswa dengan mahasiswa yang lainnya, mahasiswa dengan dosen (McEnroePetitte,2014 dalam Sumarni, 2020).Gladding (1995) dalam Nusantara et al., (2018) mengungkapkan bahwa dalam interaksi teman sebaya memungkinkan terjadinya proses identifikasi, kerjasama dan proses kolaborasi. Proses-proses tersebut akan mewarnai proses pembentukan tingkah laku yang khas pada remaja. Perilaku caring teman sebaya dapat memfasilitasi pelaksanaan perilaku caring dengan menggunakan strategi yang membantu mahasiswa untuk mengenali dan menanggapi perilaku caring selama interaksi informal dengan teman sebaya mereka di kampus, juga interaksi terapeutik ke pasien nantinya (Guyn, 1995 dalamDobrowolska et al., 2014). Menurut Semiawan (1999) dalamRahmawati(2015), menyatakan faktor-faktor yang mempengaruhi perilaku teman sebaya adalah kesamaan usia, situasi, keakraban, ukuran kelompok, dan perkembangan kognisi.

Hasil penelitian ini didukung dengan penelitian yang dilakukan oleh Sharma et al., (2016)tentang Peer Caring Behavior Among Nursing Students menunjukkan dari 306 responden ada 206 (65\%) peserta penelitian memiliki tingkat rata-rata peer caring behaviorbaik. Hubungan dengan teman sebaya memungkinkan mahasiswa untuk mengeksplorasi keterampilan caring yang penting seperti umpan balik, pengungkapan 
diri, kepercayaan dan keterampilan resolusi konflik (Collins \& Repinski, 1994 dalamSharma et al., 2016). Teman sebaya penting dalam membentuk persepsi caring mahasiswa, hal ini didukung oleh pendapat Noddings, (1992) dalam Warshawski et al., (2018)bahwa kelompok sebaya sangat berguna dalam menyediakan lingkungan dimana mahasiswa perawat dapat belajar caring.

Berdasarkan hasil analisis kuesioner perilaku caring nilai tertinggi diperoleh pada dimensi Pengetahuan dan keterampilan profesional (professional knowledge and skill) (926) yaitu pada pernyataan kuesioner Saat praktik klinik di rumah sakit, saya menjaga kerahasiaan informasi pasien. Dalam dunia kesehatan di antara tenaga kesehatan yang mengetahui kondisi pasien harus menjaga rahasia informasi pasien baik itu data pasien maupun kondisi pasien. Namun apabila dibutuhkan hanya boleh dibuka oleh orangorang tertentu.Untuk nilai terendah pada dimensi keterhubungan positif (positive connectedness) (742) pada pernyataan Saat praktik klinik di rumah sakit, saya meminta pendapat pasien dalam perawatan dirinya.Dalam suatu kondisi pada saat sakit seorang memerlukan perawatan diri.Perawatan diri hendaklah dilakukan pasien maupun dbantu oleh keluarga pasien.karena, pada kondisi sakit pasien memerlukan perawatan diri untuk terhindar dari penyakit lainnya. Oleh sebab itu perlu adanya kerja sama antara tim kesehatan dengan keluarga untuk meningkatkan perawatan diri pada pasien.

Perawat adalah suatu profesi yang sangat mulia, karena memerlukan kesabaran dan ketenangan dalam melayani pasien yang sedang menderita sakit(Dwidiyanti, 2010). Seorang perawat harus dapat melayani pasien dengan sepenuh hati. Sebagai seorang perawat harus dapat memahami masalah yang dihadapi oleh klien, selain itu seorang perawat dapat berpenampilan menarik. Untuk itu seorang perawat memerlukan kemampuan untuk memperhatikan orang lain, keterampilan intelektual, teknikal, dan interpersonal yang tercermin dalam perilaku caring atau kasih sayang (Strout, 2012 dalam Sumarni, 2020).

Perilaku caring pada mahasiswa dalam pendidikan keperawatan sangat penting karena merupakan tempat pertama bagi mahasiswa untuk belajar tentang nilai-nilai dan esensi dari profesi mereka (Begum \& Slavin, 2012). Penelitian Nadelson(2010)menyatakan bahwa perilaku caring mahasiswa keperawatan dipengaruhi oleh umur dan persepsi tentang perilaku caring teman sekelompok. Umur lebih muda, maka akan semakin caring, begitu juga ketika teman dalam satu kelompok caring, maka tim tersebut akan caring. Lamanya pendidikan keperawatan tidak berhubungan dengan perilaku caring. Nursalam et al., (2015) menyatakan bahwa perilaku caring mahasiswa dipengaruhi oleh faktor individu (demografi, pengetahuan, keterampilan), faktor psikologi (kepribadian, kecerdasan emosional, motivasi) dan faktor organisasi (beban kerja/ tugas).

Pembentukan dan pemeliharaan perilaku caring penting untuk dibentuk saat pembelajaran di bangku perkuliahan. Saat pembelajaran, mahasiswa dapat belajar tentang caring (Begum \& Slavin, 2012). Dalam penyusunan kurikulum pendidikan perawatan harus selalu memasukkan unsur caring dalam setiap mata kuliah. Penekanan pada humansitik, kepedulian dan kepercayaan, komitmen membantu orang lain dan berbagai unsur caring yang lain harus ada dalam pendidikan perawatan. Konsep saling membantu, peduli, koping, saling memberi dukungan merupakan bagian dari caring yang dapat diaplikasikan di pembelajaran keperawatan maupun saat menjadi perawat di rumah sakit (Wade \& Kasper, 2006 dalam Sumarni, 2020).

Berdasarkan hasil analisis kuesioner dukungan sosial, rata-rata responden menjawab pernyataan kuesioner tentang dukungan sosial paling banyak di pernyataan Saya menerima dukungan sosial dari anggota keluarga dekat sebagai bentuk dukungan ke 
saya untuk berperilaku caring. Pernyataan paling rendah di pernyataan Saya menerima dukungan sosial dari jejaring sosial sebagai bentuk dukungan ke saya untuk berperilaku caring.

Temuan ini sesuai dengan penelitian sebelumnya yang dilakukan Reeve, Shumaker, Yearwood, Crowell, \& Riley, (2013)dan Wolf L, Stidham AW, (2015)bahwa penggunaan berbagai sumber sosial, termasuk keluarga dan teman, untuk mengelola stres mahasiswa keperawatan selama studi. Mahasiswa keperawatan menyatakan bahwa WhatsApp grup dan Instagram merupakan tempat mereka berbagi pengalaman belajar dan menerima dukungan dari orang lain. Penggunaan media sosial adalah cara umum untuk komunikasi; hasil menunjukkan bahwa memang demikianpenting juga untuk memberikan dukungan sosial. Penelitian Tower M, Blacklock E, Watson B, Heffernan C, (2015) menyatakan bahwa peningkatan penggunaan teknologi media di antara mahasiswa keperawatan untuk dukungan sosial. Karenanya, pendidik harus menggunakan media sosial untuk mempromosikan kebutuhan dukungan siswa.

Dukungan sosial penting untuk pengembangan profesional dan pribadi mahasiswa keperawatan. Hasil penelitian sebelumnya menunjukkan dukungan sosial dari keluarga dan teman dalam bentuk penggunaan media sosial (facebook, whats app) berkorelasi positif dengan persepsi mahasiswa tentang caring.Teknologi media sosial telah menjadi sarana populer untuk menciptakan dan memelihara hubungan sosial, tetapi meskipun diasumsikan bahwa mayoritas mahasiswa keperawatan sering menggunakan media sosial, peran media sosial dalam pendidikan keperawatan belum sepenuhnya dieksplorasi (Kim Usher et all., 2014).

Berdasarkan hasil penelitian, diketahui bahwa hasil uji statistik dengan menggunakan Spearman's Rank diperoleh nilai $p$-value 0,015 dengan correlation coefficient 0,269 yang menunjukan bahwa adanya hubungan yang signifikan (berarti) antara peer caring behaviors denganperilaku caring dengan kekuatan hubungan (korelasi) sedang.

Noddings, (1992) dalam Warshawski et al., (2018)mengatakan pembentukan perilaku caring di institusi pendidikan memiliki empat elemen: role model, dialog, praktik, dan konfirmasi. Teman sebaya menyediakan empat elemen tersebut. Mahasiswa menggunakan teman sebaya mereka sebagai sumber untuk mengembangkan nilai-nilai moral.Elemen ini membutuhkan latihan secara aktif di lingkungan yang aman, di mana mahasiswa merasa bebas dari risiko dan rasa cemas/ takut serta justifikasi. Untuk alasan itu, Noddings, (1992) dalam Warshawski et al., (2018) menyarankan kelompok teman sebaya sebagai lingkungan alternatif bagi siswa untuk belajar merawat.

Hughes (1993) dalam Warshawski et al., (2018) mengatakan bahwa hubungan teman sebaya sebagai dimensi penting pengalaman pendidikan di sekolah keperawatan. Mahasiswa perawat berbagi pengalaman ketika merawat pasien pada saat praktik klinik di rumah sakit untuk meningkatkan keakraban dan memungkinkan mahasiswa untuk saling memberikan contoh bagaimana berperilaku caring.

Penelitian ini sejalan dengan penelitian Warshawski et al., (2018)tentang The Associations Between Peer Caring Behaviors and Social Support to Nurse Students' Caring Perception yang menunjukan hasil mahasiswa tahun keempat memiliki persepsi perilaku caring dan peer caring behavior lebih dari mahasiswa tahun pertama.

Penelitian juga menunjukkan bahwa terdapat hubungan dukungan sosial dengan perilaku caring mahasiswa keperawatan ( $p$ value 0,01 ) dengan kekuatan hubungan yang lemah. Hasil penelitian ini menunjukkan pentingnya dukungan sosial untuk pengembangan profesional dan pribadi mahasiswa keperawatan.

Forum media sosial digunakan oleh mahasiswa untuk mendiskusikan kegiatan 
akademik, tetapi juga sebagai sumber daya untuk dukungan emosional misalnya mahasiswa berbagi pengalaman merekadan ketika menjalani praktik di rumah sakit, mereka akansaling memberi dukungan tentang stres yang mereka rasakan ketika praktik (Tower M, Blacklock E, Watson B, Heffernan C, 2015)Duke et al., 2017). Hal ini memiliki potensi untuk meningkatkan keterampilan profesional mahasiswa dalam memberikan dan menerima umpan balik dan sebagai kesempatan untuk berlatih danmenunjukkan perilaku caring kepada teman sekelas mereka.

Berdasarkan hasil penelitianTower $M$, Blacklock E, Watson B, Heffernan C, (2015), peningkatan penggunaanteknologi media di antara mahasiswa keperawatan bermanfaat untuk dukungan sosial. Karenanya,pendidik harus menggunakan media sosial sebagai bentuk memberikan dukungan sosial. Berdasarkan hasil penelitian sebelumnya oleh Warshawski et al., (2018), dukungan sosial berhubungan dengan persepsi caring mahasiswa keperawatan.

\section{KESIMPULAN DAN SARAN}

Terdapat hubungan peer caring behaviour, dukungan sosial dengan perilaku caring mahasiswa keperawatan.Berdasarkan hasil penelitian ini, diharapkan responden dapat lebih meningkatkan perilaku caring dengan cara kelompok teman sebaya. Karena kelompok teman sebaya dapat menyediakan pembelajaran bersama dalam berbagai bentuknya (catatan bersama, pembelajaran strategi dII) dimana mahasiswa perawat dapat meningkatkan perilaku caring. Pendidik harus mempertimbangkan peran potensial yang berkembang dari teknologi media sosial sebagaisumber dukungan sosial yang dapat diakses dan sebagai media pembelajaran. Selain itu, pendidik harusmendorong pelaksanaan perilaku caring diantara teman sebaya di kalangan mahasiswa sebagai sarana memfasilitasi hubungan mahasiswa dengan pasien dan keluarganya.

\section{REFERENSI}

Baker, M. L. (2012). Nursing Student Stress And Demographic Factors. California State University.

Begum, S., \& Slavin, H. (2012). Perceptions of "caring" in nursing education by Pakistani nursing students: An exploratory study. Nurse Education Today, 32(3), 332-336. https://doi.org/10.1016/j.nedt.2011.10.011

Dobrowolska, B., Ślusarska, B., Zarzycka, D., McGonagle, I., Pawlikowski, J., \& Cuber, T. (2014). Care concept in medical and nursing students' descriptions Philosophical approach and implications for medical education. Annals of Agricultural and Environmental Medicine, 21(4), 854-860. https://doi.org/10.5604/12321966.112994 6

Duke, V. J. A., Anstey, A., Carter, S., Gosse, N., Hutchens, K. M., \& Marsh, J. A. (2017). Social media in nurse education: Utilization and E-professionalism. Nurse Education Today, 57(June), 8-13. https://doi.org/10.1016/j.nedt.2017.06.009

Dwidiyanti. (2010). Konsep Caring. Semarang: Hasani.

Kim Usher, Cindy Woods, Evan Casella, Nel Glass, Rhonda Wilson, Lidia Mayner, Debra Jackson, Janie Brown, Elaine Duffy, Carey Mather, Elizabeth Cummings, P. I. (2014). Australian health professions student use of social media,. Collegian,Volume 21(2), Pages 95-101,. https://doi.org/https://doi.org/10.1016/j.col egn.2014.02.004.

McEnroe-Petitte DM. (2015). Examining of Caring In Traditional and Non-traditional Nursing Students. Int J Nurs Clin Pract 2: 148.https://doi.org/http://dx.doi.org/10.153 44/2394-4978/2015/148

Nadelson. (2010). Nursing Student Perceptions Of Caring Behavior. Conference: 2011 Western Institute of Nursing Annual Communicating Nursing Research Conference. 
Nursalam, N., Wijaya, A., Bakar, A., \& Efendi, F. (2015). Indonesian Nursing Students in Caring Behavior. GSTF Journal of Nursing and Health Care, 2(2). https://doi.org/10.5176/2010-4804_2.2.75

Nusantara, A. F., Wahyusari, S., Studi, P., Keperawatan, S., Hafshawaty, S., \& Zainul, P. (2018). Perilaku Caring Mahasiswa Program Studi Sarjana Keperawatan. 2(1), 29-36.

Rahmawati. (2015). Pengaruh Pergaulan Teman Sebaya Dan Konsep Diri Terhadap Kecerdasan Emosional Siswa Kelas V Sd Negeri Se-Kecamatan Tegalrejo Yogyakarta. Skripsi, 13.

Reeve, K. L., Shumaker, C. J., Yearwood, E. L., Crowell, N. A., \& Riley, J. B. (2013). Nurse Education Today Perceived stress and social support in undergraduate nursing students ' educational experiences. 33, 2012-2014.

Richardson, C., Percy, M., \& Hughes, J. (2015). Nursing therapeutics: TEACHING student nurses care, compassion and empathy. Nurse Education Today, 35(5), e1-e5. https://doi.org/10.1016/j.nedt.2015.01.016

Sharma, N., Das, K., Thakur, M., Kaur, G., Chauhan, M., Kiaur, P., ... Rrahi, S. (2016). Peer Caring Behaviour Among Nursing Students . Nursing and Midwifery Research Journal, (1), 1-8. https://doi.org/10.33698/nrf0198

Sumarni. (2020). Monograf: Peran Pembimbing Klinik dalam Pembentukan Perilaku Caring dan Self Efficacy
Mahasiswa. Purwokerto: UHB Press.

Swarjana. (2014). Metodologi Penelitian. Yogyakarta.

Tower M, Blacklock E, Watson B, Heffernan C, T. G. (2015). Using social media as a strategy to address "sophomore slump" in second year nursing students: A qualitative study. Nurse Educ Today., Nov;35(11).https://doi.org/10.1016/j.nedt.2 015.06.011.

Warshawski, S., Itzhaki, M., \& Barnoy, S. (2018). The associations between peer caring behaviors and social support to nurse students' caring perceptions. Nurse Education in Practice, 31, 88-94. https://doi.org/10.1016/j.nepr.2018.05.009

Watson. (2012). Assessing And Measuring Caring In Nursing And Health Science (2nd ed). New York: Springer.

Wolf L, Stidham AW, R. R. (2015). Predictors of stress and coping strategies of US accelerated vs. generic Baccalaureate Nursing students: an embedded mixed methods study. Nurse Educ Today., Jan;35(1):https://doi.org/10.1016/j.nedt.20 14.07.005.

Zamanzadeh, V., Valizadeh, L., Azimzadeh, R., Aminaie, N., \& Yousefzadeh, S. (2014). First and Fourth-Year Student's Perceptions about Importance of Nursing Care Behaviors: Socialization toward Caring. Journal of Caring Sciences, 3(2), 93-

101.https://doi.org/10.5681/jcs.2014.010 